Review

\title{
Scope for industrial applications of production scheduling models and solution methods
}

\author{
Iiro Harjunkoski ${ }^{\mathrm{a}, *}$, Christos T. Maravelias ${ }^{\mathrm{b}}$, Peter Bongers ${ }^{\mathrm{c}, \mathrm{j}}$, Pedro M. Castro $^{\mathrm{d}}$, \\ Sebastian Engell ${ }^{\text {e }}$, Ignacio E. Grossmann ${ }^{\mathrm{f}}$, John Hooker ${ }^{\mathrm{g}}$, Carlos Méndez ${ }^{\mathrm{h}}$, \\ Guido Sand ${ }^{\mathrm{a}}$, John Wassick ${ }^{\mathrm{i}}$ \\ a ABB Corporate Research, Wallstadter Str. 59, 68526 Ladenburg, Germany \\ b University of Wisconsin, Madison, WI 53706, United States \\ ' Unilever RE'D Vlaardingen, 3133 AT Vlaardingen, The Netherlands \\ d Laboratório Nacional de Energia e Geologia (LNEG), 1649-038 Lisboa, Portugal \\ e Department of Biochemical and Chemical Engineering, Technische Universität Dortmund, 44221 Dortmund, Germany \\ ${ }^{\mathrm{f}}$ Department of Chemical Engineering, Carnegie Mellon University, Pittsburgh, PA 15213, United States \\ g Tepper School of Business, Carnegie Mellon University, Pittsburgh, PA 15213, United States \\ ${ }^{\mathrm{h}}$ INTEC (UNL - CONICET), Güemes 3450, 3000 Santa Fe, Argentina \\ ${ }^{i}$ The Dow Chemical Company, United States \\ ${ }^{\mathrm{j}}$ Eindhoven University of Technology, 5612 AZ Eindhoven, The Netherlands
}

\section{A R T I C L E I N F O}

\section{Article history:}

Received 2 May 2013

Received in revised form

12 November 2013

Accepted 3 December 2013

Available online 12 December 2013

We dedicate this paper to Prof. Dr. Peter Bongers, who inspired us all and shared his valuable experiences in the border of academia and industry and cannot be with us today to see the final result of this joint effort.

\section{Keywords:}

Scheduling

Industrial applications

Best practices

Integration

Challenges

\begin{abstract}
A B S T R A C T
This paper gives a review on existing scheduling methodologies developed for process industries. Above all, the aim of the paper is to focus on the industrial aspects of scheduling and discuss the main characteristics, including strengths and weaknesses of the presented approaches. It is claimed that optimization tools of today can effectively support the plant level production. However there is still clear potential for improvements, especially in transferring academic results into industry. For instance, usability, interfacing and integration are some aspects discussed in the paper. After the introduction and problem classification, the paper discusses some lessons learned from industry, provides an overview of models and methods and concludes with general guidelines and examples on the modeling and solution of industrial problems.
\end{abstract}

(c) 2013 Elsevier Ltd. All rights reserved.

\section{Contents}

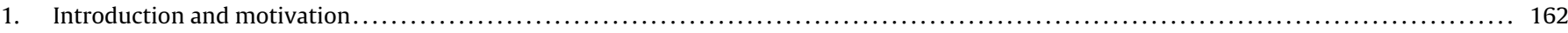

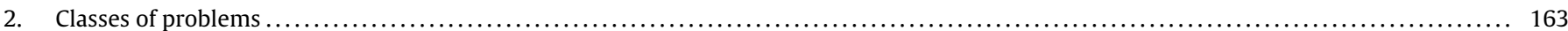

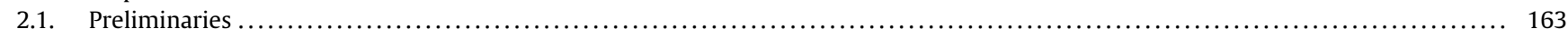

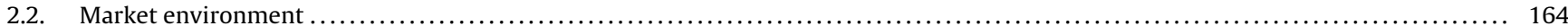

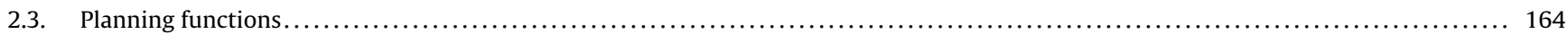

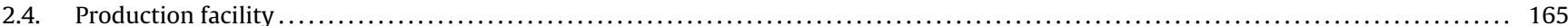

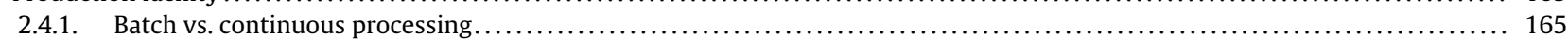

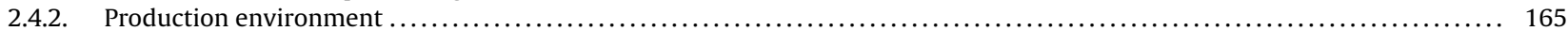

\footnotetext{
* Corresponding author. Tel.: +49 (0) 1713322306.

E-mail address: iiro.harjunkoski@de.abb.com (I. Harjunkoski).
} 